\title{
ARSITEKTUR RUMAH ADAT KAMPUNG KEPUTIHAN
}

\author{
Oleh Yuzar Purnama \\ Balai Pelestarian Sejarah dan Nilai Tradisional Bandung \\ Jln. Cinambo No. 136 Ujungberung Bandung \\ Email: Yuzarpurnama@yahoo.com \\ Naskah diterima: 19 Maret 2010 \\ Naskah disetujui: 27 Mei 2010
}

\begin{abstract}
Abstrak
Kampung Keputihan merupakan kampung adat yang berlokasi di wilayah Sumber, Kecamatan Weru, Kabupaten Cirebon, Provinsi Jawa Barat. Sebagai masyarakat adat dalam kehidupan sehari-harinya masih menjaga dan memelihara adat istiadat leluhurnya termasuk arsitektur rumah. Sementara itu, di masyarakat khususnya generasi muda banyak yang tidak mengetahui produk budaya daerah termasuk di dalamnya arsitektur rumah tradisional. Penelitian arsitektur rumah tradisional di Kampung Keputihan meliputi struktur, teknik membangun, persiapan dan pelaksana, serta upacara tradisional yang menyertainya. Penelitian ini menggunakan metode kualitatif dan deskripsi analisis. Arsitektur rumah tradisional di Kampung Keputihan masih mengikuti kaidah-kaidah yang diwariskan dari leluhurnya, namun sebagian sudah mengalami pergeseran-pergeseran misalnya lantai yang sudah ditembok dan genting sudah menggunakan asbes dan seng, serta sudah tidak memiliki lagi lumbung padi dan bale musyawarah.
\end{abstract}

Kata kunci: arsitektur, kampung adat.

\section{Abstract}

Kampung (village) Keputihan is a traditional village located in the region of Sumber, Kecamatan (district) Weru, Kabupaten (regency) Cirebon, West Java Province. The people of Kampung Keputihan preserve their traditional way of life, including traditional architecture. But this knowledge is not common in young generation. In building their houses the community of Kampung Keputihan follow principles that were passed on for generations. Of course, there are some modifications. Some elements such as lumbung padi (rice storage) and bale musyawarah (a place where the community meeting take place) are no longer available in the kampung. Techniques in building the houses, the building structure, as well as traditional ceremony following it, are the foci of this research. The methods of analysis are qualitative and descriptive.

Keywords: Architecture, Indigenous Village.

\section{A. PENDAhuluan}

Unsur-unsur kebudayaan daerah pada suku bangsa yang tersebar di berbagai daerah di Indonesia merupakan sumber yang potensial bagi terwujudnya kebudayaan nasional, yang memberikan corak monopluralistik, tetapi sesungguhnya tetap satu "Bhineka Tunggal Ika". Salah satu unsur kebudayaan yang kini masih tetap hidup dan dijadikan sebagai tuntunan serta pedoman dalam 
kehidupan sehari-hari oleh suku-suku bangsa di Indonesia adalah arsitektur tradisional.

Arsitektur tradisional sebagai salah satu unsur kebudayaan sebenarnya tumbuh dan berkembang seiring dengan pertumbuhan suatu suku bangsa. Oleh karena itu, tidaklah berlebihan jika dikatakan bahwa arsitektur tradisional merupakan suatu hal yang dapat memberikan ciri serta identitas suku bangsa sebagai pendukung suatu kebudayaan tertentu.

Wilayah Negara Kesatuan Republik Indonesia (NKRI) memiliki khasanah kebudayaan yang memberikan identitas dan jatidiri suatu suku bangsa. Sementara itu, dari 34 provinsi ini terdiri atas 500 suku bangsa. Suku bangsa yang banyak tersebut memiliki latar belakang kebudayaan dan tradisi yang beraneka macam. Identitas yang membedakan suatu suku bangsa dengan suku bangsa lainnya di antaranya adalah arsitektur tradisional yang menghiasi bangunan tempat mereka hidup dan melakukan segala aktivitas sehari-hari. Dari data yang ada belum semua bangunan tradisional di Indonesia diinventarisasi apalagi dilakukan penelitian terhadap aspek-aspek yang melatar belakanginya. Selain itu, generasi penerus bangsa saat ini belum bahkan tidak mengetahui khasanah arsitektur tradisional yang dimiliki bangsanya. Oleh karena itu penelitian perlu dilakukan agar mereka tidak kehilangan identitas dan jatidiri bangsanya.

Di samping itu, seiring dengan semakin pesatnya pembangunan di berbagai bidang telah menyebabkan keberadaan arsitektur tradisional tergerus oleh perkembangan jaman. Permasalahan inilah yang mendorong dilakukannya kegiatan penelitian terhadap bangunan arsitektur tradisional Rumah Adat di Kampung Keputihan Kabupaten Cirebon Provinsi Jawa Barat.

Penelitian ini bertujuan untuk mendapatkan gambaran yang lengkap dan jelas tentang arsitektur tradisional Rumah Adat di Kampung Keputihan, kemudian setiap data yang terkumpul dikaji dari sudut fungsional dan simbolisnya. Adapun tujuan lengkapnya adalah menggali pengetahuan dan teknologi tradisional tentang Rumah Adat, menyediakan data tentang arsitektur tradisional, dan meningkatkan pengetahuan masyarakat tentang arsitektur tradisional.

Ruang lingkup penelitian arsitektur tradisional rumah ini hanya dibatasi pada arsitektur Rumah Adat yang terdapat di Kampung Keputihan Kabupaten Cirebon Provinsi Jawa Barat yang melingkupi bentuk dan tata ruang bangunan, tatacara mendirikan bangunan, upacara yang menyertainya, fungsi serta simbol yang terkandung dalam arsitektur rumah tersebut.

Batasan tentang arsitektur tradisional telah banyak diberikan oleh para ahli. Batasan-batasan tersebut secara keseluruhan dapat disimpulkan bahwa arsitektur tradisional merupakan suatu bangunan yang bentuk, struktur, fungsi, ragam hias, dan cara membuatnya diwariskan dari suatu generasi ke generasi berikutnya, serta dapat dimanfaatkan sebagai tempat untuk melaksanakan aktivitas kehidupan.

Dari hasil penelitian arkeologis yang telah dilaksanakan terhadap 
semua peninggalan arsitektur tradisional di wilayah Nusantara, dapat diketahui bahwa berdasarkan fungsinya dapat dibedakan menjadi dua jenis, yaitu bangunan profan seperti rumah tempat tinggal dan bangunan sakral/suci seperti rumah adat, bangunan tempat-tempat ibadah, dan sebagainya. Pada bangunan-bangunan profan umumnya banyak yang sudah mengalami perubahan-perubahan karena dibuat dengan bahan/material yang kurang kuat, sedangkan bangunan-bangunan yang bersifat sakral biasanya dibuat dengan bahan/material yang lebih kuat dan tahan lama, serta sedikit mengalami perubahan, karena adanya keyakinan akan kesucian (Wayan Suantika, 2005: 8-11).

Metode yang digunakan pada penelitian ini adalah metode deskripsi analisis, yaitu penelitian dilaksanakan semata-mata berdasarkan kepada fakta yang ada. Data yang terkumpul diberi interpretasi sesuai kebutuhan. Adapun penelitian ini tentunya menggunakan pendekatan kualitatif.

Penelitian diawali dengan studi pustaka untuk memperoleh pengetahuan teori. Langkah berikutnya pengumpulan data. Data yang telah dikumpulkan kemudian diklasifikasi dan dianalisis, hasil analisis disusun menjadi sebuah laporan. Metode yang digunakan dalam pengumpulkan data adalah observasi; mengamati secara langsung bentuk fisik dan unsur-unsur yang membentuk bangunan. Wawancara; diperlukan untuk mendapatkan keterangan dan data dari individu untuk keperluan informasi tentang nilai-nilai, makna dan fungsi yang berkaitan dengan arsitektur tradisional. Studi Kepustakaan; dilakukan untuk melengkapi data primer yang diperoleh melalui kedua metode di atas.

\section{B. HASIL DAN BAHASAN}

Kampung Adat Keputihan terletak di Sumber, Kecamatan Weru, Kabupaten Cirebon, masyarakatnya masih memegang teguh adat istiadat warisan dari leluhurnya. Bangunan tradisional di Kampung Adat Keputihan masih relatif asli, walaupun sudah ada perubahan misalnya atap yang seharusnya menggunakan bahan dari dedaunan seperti daun kelapa dan daun tebu sekarang ada yang menggunakan seng dan asbes, begitu juga lantai yang seharusnya tanah ada beberapa rumah yang sudah menggunakan peluran (adukan semen dengan pasir). Jumlah bangunan rumahpun sekarang sudah berkurang karena ada beberapa warga yang keluar dari Kampung Keputihan dengan alasan ingin memiliki bangunan permanen.

Bangunan tempat musyawarah di Kampung Adat Keputihan sudah tidak ada lagi, sekarang mereka kalau melaksanakan musyawarah menggunakan rumah Ketua Rukun Tetangga (RT) atau tetua adat. Begitu pula lumbung padi atau tempat menyimpan padi sehabis panen di Kampung Adat Keputihan sudah tidak ada, dulu memang ada akan tetapi sekarang sudah tidak ada. Alasannya sekarang ini padi hasil panen di sawah tidak perlu lagi disimpan ke lumbung tapi dimasukkan kedalam karung dan dijual ke warung atau kepada bandarbandar yang biasa menampung padi langsung dari sawah selepas panen. 
Luas tanah adat di Kampung Keputihan 10 hektar, tanah ini disebut juga sebagai tanah kesucian; orang di sini menurut leluhur dirinya adalah suci. Dari kata kesucian inilah munculnya nama keputihan, nama tersebut muncul dari penuturan terlalu cepat dan ada juga yang berpendapat dari kesamaan (sinonim) "suci" adalah putih seperti bajunya putih sesuci hatinya.

Kampung Adat Keputihan di Kabupaten Cirebon dulunya terdiri atas tujuhbelas (17) rumah, kini yang ada hanya tigabelas (13) rumah. Menciutnya rumah adat ini disebabkan oleh warga pindah ke tempat lain diluar areal kampung adat. Mereka merasa mampu untuk membangun rumah permanen yang beratap genting dari tanah liat, ada juga yang pindah karena sudah tidak kuat hidup dengan memelihara dan menjaga adat istiadat leluhur (nenek moyang), ingin bebas.

Luas areal Kampung Adat Keputihan yang 10 hektar ditempati oleh 13 rumah (umpi). Mereka yang menetap dan tinggal di sana harus tetap mempertahankan dan memelihara adat istiadat leluhur, Jika sudah tidak mau atau tidak sanggup hidup dengan menggunakan adat istiadat setempat, maka harus keluar dari lingkungan Kampung Adat Keputihan.

Adat istiadat yang masih berlaku di Kampung Adat Keputihan selain kepercayaan terhadap keberadaan leluhur yang selalu melindungi dan mengayomi mereka juga memelihara larangan-larangan seperti rumah tidak boleh menggunakan tembok, jendela tidak boleh dengan kaca, atap hanya boleh menggunakan dedaunan seperti daun Tebu dan daun Kelapa, sumur tidak boleh berada di posisi sebelah kiri rumah, dan sebagainya. Pelanggaran terhadap adat istiadat leluhur akan mendapatkan sangsi. Istilahnya kualat, bentuk kualat itu di antaranya akan kena penyakit yang tidak sembuhsembuh atau disulitkan mencari rejeki seperti mendapat kesulitan makan dan sebagainya.

Letak Rumah Adat Keputihan tidak jauh dari jalan utama yang dilalui oleh angkutan umum seperti Angkutan Pedesaan (angdes). Selepas angkutan umum dapat dilanjutkan dengan berjalan kaki atau naik ojek. Dengan melewati pesawahan yang jaraknya ratusan meter maka tibalah di seuah perkampungan; perkampungan ini adalah pembauran antara Kampung Adat Keputihan dengan perkampungan biasa. Pemisah antara kampung dengan kampung adat hanyalah kebun biasa, bahkan orang yang lewat tidak dapat membedakannya selain bentuk bangunannya.

Memasuki area Kampung Adat Keputihan tampaklah bangunan pertama yang beratapkan daun kelapa/tebu dan berlantai tanah yang ditinggikan $30-50 \mathrm{~cm}$ dari permukaan tanah. Selanjutnya beberapa rumah akan kelihatan kembali dengan jarak yang cukup terpisah oleh kebun. Antara rumah yang satu dengan yang lainnya tidak tertata rapih dan jarak yang satu dengan yang lainnya agak berjauhan.

Posisi rumah mengarah ke selatan dan bagian belakangnya ke arah utara atau boleh juga mengarah ke utara. Sedangkan posisi sumur dan tempat mandi harus ada di sebelah kanan agak ke belakang. Jika posisi sumur di sebelah kiri rumah dianggap 'sama dengan makan bangkai'. 
Kalaupun ada bangunan kamar mandi di sebelah kiri rumah, itu hanya difungsikan sebagai tempat untuk mencuci dan mandi.

Sumur sebagai sumber air untuk keperluan masak memasak, minum, mencuci pakaian dan perabot rumah tangga merupakan kebutuhan primer bagi masyarakat setempat. Sumur dibangun secara gotong royong; sumur memiliki bentuk bulat dengan kedalaman bervariasi mulai dari tiga meter sampai sepuluh meter, dengan diameter kurang lebih satu meter, ketinggian tembok atau dinding sumur sekitar 60-100 cm. Sebelah sumur dilengkapi dengan sebuah bangunan tertutup dengan atap dedaunan dan dinding terbuat dari bilik kurang lebih berukuran $2 \times 3$ meter persegi. Bangunan tersebut merupakan tempat untuk mandi; tempat mandi atau lazim disebut kamar mandi bisa ditempatkan di sebelah kiri atau kanan posisi rumah.

Alat untuk mengambil air dari sumur menggunakan ember karet yang diikatkan pada tali karet yang panjangnya harus lebih dalam dari permukaan air. Tali karet digantungkan ke sebuah roda yang menggunakan laher atau disebut eretan/penggerek yang digantung diatas kayu atau pipa besi disangga dengan dua tiang yang ditancapkan di samping tembok sumur.

Rumah beratapkan daun tebu/ kelapa yang disebut pucung. Jadi "pucung" atau atapnya terbuat dari daun tebu atau daun kelapa, tidak boleh dari bahan lain termasuk genting yang terbuat dari tanah liat dan atap seng atau asbes. Atap ini biasanya hanya kuat sampai 1,5 tahun dan harus diganti dengan daun Tebu yang baru. "Pucung" adalah rangkaian daun Tebu yang disusun pada sebilah bambu.
Daun Tebu dilipat simetris kemudian dililitkan pada potongan bambu yang panjangnya sekitar dua meter kemudian diurai agar kedua ujung daun Tebu berpadu. Jadi atap batang daun Tebu itu panjangnya dua meter sedangkan lebarnya sekitar 40 sentimeter. Untuk satu rumah dibutuhkan sekitar 500 batang untaian daun tebu/pucung.

Penyangga rumah seperti tiang, soko guru, wuwung, kuda-kuda, palang terbuat dari kayu sedangkan reng dapat terbuat dari kayu atau bambu. Begitu pula bentuk pintu ada yang terbuat dari kayu ada juga yang terbuat dari anyaman bambu. Tipe pintu ini ada dua macam yaitu pintu yang diayun dengan menggunakan engsel dan pintu yang digeser dengan meggunakan lubang panjang sebagai tempat geseran atau sorolok. Pintu yang diayun terbuat dari kayu adapun pintu yang digeser terbuat dari bambu dengan anyaman bilik.

Dinding rumah terbuat dari bambu yang dianyam disebut bilik. Bilik menutupi seluruh bagian yang memisahkan antara rumah dengan bagian luar dan memisahkan antara satu ruangan dengan ruangan lainnya. Rumah memiliki jendela untuk ventilasi (lubang angin) dan pencahayaan. Jendela di tempatkan di dinding rumah bagian muka sebelah kiri dan kanan.

Jendela adalah tempat masuknya udara (cirebon: hawa), fungsinya sebagai bagian sirkulasi udara atau oksigen yang dibutuhkan oleh manusia. Jendela di masyarakat adat Keputihan bentuknya tidak seperti umumnya jendela di perkotaan bentuknya persegi panjang dengan tidak menggunakan penutup seperti daun jendela, jadi kalau malam hari akan selalu terbuka. Ukuran jendela kurang lebih 40x60 cm, 
jendela memiliki ruji/jeruji atau tralis yang terbuat dari bambu berfungsi sebagai lubang angin-angin. Jendela ini berfungsi dan dianggap sebagai tempat untuk mengeluarkan penyakit dari rumah, sehingga setiap hari udara di dalam rumah akan steril atau bersih dari kuman penyakit dan debu. Di musim hujan agar udara tidak terasa dingin, jendela ditutup dengan plastik dan untuk lubang udara, plastik tersebut dilubangi.

Bagian jendela yang merupakan bagian terbuka dari rumah, biasanya si empunya rumah di masyarakat adat memasang "singlar atau panyinglar" semacam tolak bala. Menurut informan perlengkapan singlar yang terdiri atas bawang merah dan bawang putih yang ditusuk sate fungsinya untuk mengusir gangguan mahluk halus, dalam hal ini Kuntilanak.

Lantai rumah harus dari tanah tidak boleh bentuk peluran semen atau keramik, selain dari tanah bisa juga dengan susunan bata merah yang dipasang secara horisontal kemudian celah-celahnya dilapisi dengan tanah bukan dengan adukan semen atau pelesteran. Lantai rumah lebih tinggi dari permukaan tanah, tingginya sekitar $30-50 \mathrm{~cm}$, kemudian bagian pinggir (dinding) supaya tidak mudah ambruk atau ambrol dihalangi dengan susunan bata merah yang disusun secara vertikal dengan lapisan dari tanah, tidak boleh dilapisi atau disisipkan adukan semen (ditembok). Permukaan lantai yang lebih tinggi dari permukaan tanah fungsinya agar lantai tidak lembab dan basah saat turun hujan.

Bagian depan rumah, sebelah atas rumah adalah dinding bilik berbentuk segitigasamakaki, di atap bagian depan ujungnya agak ditonjolkan kurang lebih panjangnya sekitar $1 \mathrm{~m}$. Bagian yang menonjol fungsinya adalah untuk melindungi dinding rumah dari cipratan air hujan. Kemudian pada bagian bawah ada sorondoyan (Bahasa: Sunda) atap yang dibuat ditempelkan pada dinding muka rumah secara horizontal dengan bagian sisi ujung lebih menukik daripada sisi yang lainnya yang menempel pada dinding. Sorondoy ini disebut juga jurai yang fungsinya sebagai atap untuk melindungi beranda dari terik sinar matahari dan cipratan air hujan. Selain itu, dengan adanya jurai tampak rumah lebih indah, artistik, dan anggun.

Beranda rumah merupakan bagian depan rumah yang terletak di luar rumah. Beranda fungsinya untuk si empunya rumah duduk-duduk atau berdiri di depan rumah sambil istirahat bercengkerama dengan anggota keluarga dan tetangga. Kadang dijadikan tempat untuk menyambut tamu yang tidak formal (resmi), misalnya ngobrol dengan tetangga. Di beranda disediakan sebuah bangku terbuat dari bambu yang alasnya terdiri atas bilahan bambu yang disusun secara horizontal, panjang sekitar 2-3 m, lebar $40-50 \mathrm{~cm}$, tinggi $50-60 \mathrm{~cm}$.

Warga yang memelihara hewan ternak seperti ayam, tempat menyimpan kandang dipilih dengan memanfaatkan lahan kosong di samping kanan bagian depan rumah. Kandang tidak menempel pada bagian rumah, hal tersebut untuk menghindarkan dari penyakit, kutu, dan bau kotoran hewan. Letak kandang cukup jauh dari rumah sekitar 10 meteran. 
Dalam tata ruang rumah pada masyarakat Cirebon ada satu ketentuan adat istiadat bahwa pintu masuk dan pintu keluar tidak boleh sama dalam garis lurus, akan tetapi harus dibelokan. Hal ini bermakna jika ada dalam satu garis lurus maka rejeki yang diterima akan cepat habis, tidak ada bekasnya seperti angin yang masuk dari pintu depan langsung keluar melalui pintu belakang tanpa ada halangan. Kalau dibelokan maka rejeki akan awet dan lama habisnya.

Pembagian ruangan atau denah rumah di Kampung Adat Keputihan adalah sebagai berikut: ukuran rumah $7 \times 10 \mathrm{~m}$, ukuran kamar tidur rata-rata $3 \times 3$, ruang tamu dan keluarga $4 \times 6$, ruang makan $4 \times 3$ dan di bagian belakang rumah ada ruangan yang terdapat di sebelah kanan dengan ukuran $2 \times 3$; ruangan ini fungsinya sebagai dapur dan gudang untuk menyimpan peralatan seperti cangkul, parang, dan sebagainya. Dilihat dari depan seolah rumah dibelah menjadi dua bagian, sebelah kanan 3 buah kamar tidur yang berjejer dari depan ke belakang, sebelah kiri ruangan tamu dan keluarga, serta ruang makan. Antara ruang tamu (keluarga dengan ruang makan dibatasi dinding bilik dan pintu. 2 buah kamar tidur terdapat di depan berdampingan dengan ruang tamu (keluarga), ruangan tersebut ditempati oleh anak-anak, sedangkan sebuah kamar tidur di belakang berdampingan dengan ruang makan ditempati oleh orang tua.

Jumlah kamar di setiap rumah disesuaikan dengan kebutuhan; artinya jika anggota keluarga lebih banyak maka jumlah kamarnya pun lebih banyak. Dalam sebuah rumah harus ada ruang keluarga merangkap ruangan tamu, kemudian kamar orang tua dan kamar anak, ruang makan serta di bagian luar sebelah belakang yang masih menempel ke rumah ada sebuah ruangan yang fungsinya sebagai dapur dan sekaligus gudang. Dapur tidak berada di dalam rumah berkaitan dengan kesehatan untuk menghindari adanya "sawang"; debu atau asap hitam yang biasa nempel di langit-langit. Hal ini disebabkan masyarakat adat masih menggunakan tungku api dengan bahan bakar dari kayu yang asapnya banyak dan hitam.

Ruangan/kamar orang tua berada di bagian belakang sementara kamar di bagian depannya diisi oleh anak-anak. Orang tua di bagian belakang supaya mudah untuk ke dapur, menyiapkan makanan bagi seluruh anggota keluarga. Lantai tanah di ruangan keluarga ditutupi tikar atau samak. Ruangan ini digunakan anggota keluarga untuk bercengkerama sambil menikmati hiburan televisi, sementara sebagian lagi disediakan kursi dan bangku yang terbuat dari bambu. Kursi dan bambu ini adalah untuk menerima tamu yang berkunjung ke rumah baik saudara maupun tetangga.

Atap (suhunan) rumah yang terdapat pada masyarakat Kampung Adat Keputihan menggunakan tipe suhunan pelana. Tipe suhunan pelana adalah tipe suhunan yang memanjang dari ujung Barat ke ujung Timur. Tipe suhunan ini diminati karena memiliki nilai ekonomis yang tinggi, di samping lebih sederhana dan bersahaja. Begitu pula tipe suhunan di Cirebon umumnya menggunakan tipe pelana dan malang semirang; malang semirang ini merupakan pengembangan dari pelana. Namun umumnya di Cirebon setiap rumah menggunakan tipe suhunan 
pelana, tipe suhunan atap yang lurus dari depan ke belakang, sehingga dengan atap atau suhunan pelana orang bisa lebih menghemat bahan. Dengan suhunan pelana ini sekarang lebih berkembang karena rumah yang dulunya hanya ruangan-ruangan dalam saja sekarang sudah ada teras (beranda). Bagi golongan masyarakat menengah ke atas atau golongan orang kaya biasanya menggunakan tipe atap limasan atau jurei. Jadi dengan melihat tipe atap rumah dapat dengan mudah membedakan mana rumah orang kaya dan mana rumah masyarakat biasa. Adapun bagian kerangka suhunan seperti kuda-kuda yang berfungsi sebagai penyangga suhunan hampir sama dengan kuda-kuda yang terdapat di masyarakat lain seperti Bandung dan daerah-daerah lainnya.

Jemuran; alat untuk menjemur pakaian berada di bagian depan rumah. Biasanya memanfaatkan batang pohon yang ada di halaman rumah kemudian tali kawat atau tambang plastik direntangkan di antara kedua batang pohon. Jika jarak antara kedua pohon agak jauh akan tampak tali melengkung ke bawah, untuk mengatasinya dibuatkan tiang dari bambu sebagai penyangga tali agar tidak mengendur.

\section{Mendirikan Bangunan}

Pada masyarakat tradisional maupun moderen ketika akan mendirikan rumah tentunya harus mempersiapkan langkah-langkah matang agar keinginan untuk mendirikan bangunan tersebut hasilnya sesuai dengan keinginan. Langkahlangkah yang harus direncanakan secara matang adalah persiapan.

Pada masyarakat tradisional khususnya masyarakat adat Kampung
Keputihan, sebelum mendirikan bangunan untuk tempat tinggal, ada beberapa tahap yang perlu dilakukan yaitu musyawarah, penentuan tempat dan pengadaan bahan. Untuk mendirikan bangunan tradisional tahap pertama adalah diadakannya musyawarah atau perundingan. Musyawarah ini bentuknya tidak formal, musyawarah pertama adalah perundingan antara suami dan istri. Apabila sudah mencapai kata sepakat antara suami dan istri, maka langkah berikutnya adalah menghubungi keluarga dekat atau kerabat untuk mengadakan. Pada tahap ini pihak keluarga menyampaikan rencana membangun rumah, kemudian melakukan musyawarah dengan masyarakat dekat misalnya para tetangga, karena pada masyarakat tradisional kental dengan kebersamaan gotong royongnya.

Setelah melaksanakan tahap musyawarah baru menuju kepada tahap yang kedua yaitu pemilihan tanah. Pada pembangunan rumah biasanya tanah berasal dari warisan orang tua atau dengan cara membeli dari orang lain. Sedangkan pada pembangunan rumah ibadah biasanya tanah berasal dari anggota masyarakat yang mewakafkan tanahnya untuk kepentingan umum dan agama. Pengadaan tanah biasanya terjadi pada tahap musyawarah ada anggota musyawarah yang mewakafkan tanahnya untuk sarana ibadah. Sedangkan di masyarakat adat, khususnya di Kampung Keputihan lahan tanah untuk membangun rumah pada saat ini cukup memadai, asalkan mau memelihara dan menjaga adat istiadat leluhurnya.

Tahap persiapan terakhir, setelah musyawarah dan pemilihan tanah 
adalah tahap pengadaan bahan. Mereka yang akan membangun rumah biasanya terlebih dahulu mengumpulkan bahanbahan bangunan dengan cara mencicil misalnya kayu, bata, pucung, bilik, dan bambu. Setelah dianggap mencukupi dan menyiapkan dana (anggaran), barulah ke tahap untuk membangun. Sebelum hari-H, terlebih dahulu meminta restu serta petunjuk kepada orang-orang yang dianggap berkompeten seperti sultan, tokoh masyarakat, tokoh adat, dan para sesepuh yang dianggap menguasai dan dapat menghitung hari baik.

\section{Teknik Pembuatan}

Pembangunan rumah di Kampung Adat Keputihan dikerjakan dengan sederhana, setelah semua bahan tersedia dan pekerja sudah siap maka pembangunan pun dimulai. Pembangunan dimulai dengan menggali tanah untuk pemasangan kaki atau fondasi. Tanah digali dan ditinggikan kurang lebih setengah meter kemudian disiapkan untuk pemasangan tiang-tiang. Setelah kakikaki atau fondasi kuat dipasanglah tiang-tiang kemudian diikat dengan palang agar tiang dapat berdiri kokoh dan beban bisa terbagi. Tiang yang lengkap sudah terpasang kemudian dilanjutkan dengan pemasangan bagian atap termasuk pemasangan suhunan (wuwung), kemudian disiapkan untuk menutupinya dengan daun Tebu/Kelapa. Setelah atap terpasang rapih dan tertutup dilanjutkan dengan pemasangan bilik-bilik untuk menutupi bagian dinding yang memisahkan dengan bagian luar serta dinding yang memisahkan antara satu ruangan dengan ruangan lain. Bilik yang menutupi dinding bagi masyarakat adat
Keputihan disebutnya "pagar". Dilanjutkan dengan memasang langitlangit yang bahannya sama dari bilik; bilahan bambu yang dianyam, dan bilik yang dipasang di atas langit-langit namanya "tiang". Selanjutnya pemasangan pintu baik pintu keluarmasuk maupun pintu kamar.

\section{Tenaga Pelaksana}

Pelaksana atau pekerja bangunan dibagi dua kategori yaitu pelaksana profesional atau tukang yang ahli dalam bidangnya seperti tukang kayu, gali, dan laden. Sedangkan pelaksana lainnya adalah para pekerja gotong royong yang tidak diupah. Para pekerja ini tidak memiliki keahlian dalam bidang bangunan, tugasnya hanya membantu meringankan pekerja profesional dan mempercepat penyelesaian. Mereka sudah biasa melakukan kegiatan gotong royong untuk membantu tetangganya yang sedang membangun.

Para pelaksana atau tukang mendapatkan upah harian disesuaikan dengan tingkat keterampilan yang dimilikinya, misalnya ada tukang dan ada laden. Tukang adalah orang yang menjadi pelaksana atau pekerja utama sedangkan laden adalah yang mendampingi atau membantu tukang. Upah tukang lebih besar daripada laden. Selain upah harian, nanti setelah selesai bangunan ada upah dari hasil upacara ritual "jual beli". Jumlah pelaksana atau tukang yang mengerjakan rumah berbeda disesuaikan dengan kebutuhannya. Pada masyarakat adat Keputihan yang bentuk dan struktur rumahnya sederhana misalnya untuk ukuran rumah kurang lebih $7 \times 10$ membutuhkan 2 sampai 3 orang saja. 


\section{Upacara}

\section{a. Sebelum Mendirikan Bangunan}

\section{Upacara Buka Kaki}

Mendirikan rumah pada

masyarakat adat Kampung Keputihan

diwarnai dengan berbagai upacara adat seperti upacara Buka Kaki. Upacara Buka Kaki dilaksanakan sebelum melakukan penggalian tanah untuk fondasi rumah. Tanah yang sudah ditetapkan untuk dijadikan kaki atau fondasi rumah malam harinya harus dimelekin; artinya pada malam hari dilakukan ritual dengan cara tempat (tanah) yang akan digali ditunggu semalaman. Si penunggu harus melek, tidak boleh tidur semalaman. Orang yang menunggu matanya harus terjaga di tempat tersebut. Upacara ini dilengkapi dengan seperangkat sesaji dengan nasi tumpeng, bekakak ayam dan sebagainya.

Selain itu, upacara Buka Kaki dilaksanakan untuk menentukan titik sumur sebagai sumber penyediaan air bersih. Pada waktu mau melekan sebelumnya si empunya rumah atau masyarakat memotong daun keladi atau daun pisang. Daun keladi atau daun pisang ditelungkupkan di permukaan tanah seputar halaman rumah. Keesokkan harinya daun tersebut dibuka maka dilihat daun mana yang paling banyak embunnya atau percikan airnya. Di tempat yang ditemukan embun atau percikan air paling banyak pada daun ditetapkan sebagai sumur.

Upacara Buka Kaki dimulai setelah salat Magrib atau ba'da salat Magrib. Setelah peserta upacara selametan berkumpul kemudian dimulai dengan doa-doa, salawat, dan diteruskan dengan tahlil yaitu membacakan lapaz-lapaz wiridan dan kalimat lailahaillallah beberapa kali. Orang yang memimpin doa, wirid, dan tahlil adalah sesepuh masyarakat biasanya ustadz atau guru mengaji di mesjid. Kemudian selesai doa dan tahlil semua yang hadir makan bersama menyantap hidangan yang telah disediakan. Selanjutnya setelah selesai makan-makan ada peserta yang terus melanjutkan untuk melekan ada pula yang pulang. Namun bagi si pemilik rumah atau calon pemilik rumah harus mengikuti melekan sampai pagi, sampai dimulainya "Buka Kaki" untuk menggali tanah sebagai awal prosesi penetapan fondasi rumah.

Selama melekan ada yang berwirid ada pula yang ngobrol. Namun sebelumnya diadakan terlebih dahulu tahlilan dengan membaca beberapa doa, shalawat kepada Nabi Muhammad saw. dan lapaz-lapaz tahlil. Setelah tahlilan dilanjutnya dengan melekan, apakah akan diteruskan dengan wirid baca Alquran atau mau ngobrol-ngobrol saja. Sebelum melekan terlebih dahulu harus menyediakan persyaratan seperti juadah pasar (makanan jajanan pasar, ikan ketek, wedang kawah seperti bajigur, wedang teh pahit, dan kopi) dalam satu wadah yang diletakkan di tempat yang akan digali menjadi sumur.

Setelah melekan si empunya hajat harus mengantongi perhitungan dari para sesepuh atau tetua adat tentang kapan dilakukan penggalian fondasi pertama kali, apakah harus malam itu atau esok harinya, pagi atau siang hari. Semua tergantung perhitungan "badannya" si empunya hajat, kalau pagi langsung subuh itu juga dicangkul. Pencangkulan ini 
hanyalah membuka tanah pertama kali sedangkan selanjutnya akan diteruskan oleh para pekerja (tukang). Orang yang pertama kali mencangkul tanah adalah si empunya hajat yaitu kepala keluarganya, Sang Bapak. Semua tatacara sudah ditentukan sebelumnya seperti waktu (hari dan jam berapa), doa, dan arah, misalnya pada ayunan cangkul pertama harus menghadap kiblat dengan membacakan dua kalimat sahadat atau baca bismillah, berniat dan dilaksanakan hari tertentu saja. Penentuan ini adalah hasil bertanya kepada Sultan, sesepuh atau kuncen di Gunung Jati, Kuncen Makam Keramat Cakrabuana, dan sebagainya

Tujuan upacara Buka Kaki adalah untuk tetap memelihara dan menjaga tradisi atau adat istiadat warisan leluhur (nenek moyang) juga untuk mencari keselamatan, perlindungan, dan si penghuni dapat betah di rumah yang baru, juga para pekerja yang selama ini membantu pembangunan rumah mendapatkan keselamatan, berkah dan rahmat dari Allah swt.

Pelaksanaan upacara ini sekaligus sebagai ucapan kulo nuwun dari si empunya hajat yang akan mendirikan rumah kepada makhluk gaib yang menunggu tempat tersebut. Permintaan izin sekaligus memohon agar si penunggu pindah ketempat lain dengan tidak merasa terusir, dan jangan mengganggu ketentraman dan keselamatan para pekerja (tukang) dan penghuni rumah di kemudian hari. Hal tersebut dilakukan karena masyarakat adat masih mempercayai bahwa di setiap tempat seperti tanah, air, sungai, gunung, dan pohon ada penghuninya.

Orang-orang yang terlibat pada upacara Buka Kaki selain para tukang, keluarga yang empunya rumah beserta kerabatnya, juga tetangga sekitar, dan ustadz atau tokoh agama setempat. Masyarakat setempat atau tetangga tidak selamanya harus diundang untuk mengikuti melekan, karena umumnya di sana masyarakat akan datang sendiri jika ada orang yang melakukan upacara "Buka Kaki". Masyarakat yang akan mengikuti ritual melekan biasanya membawa bekal makan masing-masing seperti pisang, kacang, dan cemilan lainnya untuk disantap saat melekan.

Pemilik rumah yang melekan diwakili oleh bapaknya yang mewakili seluruh anggota keluarga. Jika suatu saat si bapak ngantuk tidak ada larangan harus dipasakan melek, boleh tidur tetapi harus di tempat melekan yang dipasang tenda. Di tenda itu semua yang mengikuti upacara melekan berkumpul dan jika ngantuk di sana tidur. Karena yang dimaksud ritual melekan adalah berdiam diri di tempat yang telah ditentukan yaitu tempat yang direncanakan akan dijadikan "kaki" atau fondasi rumah.

Jalannya atau kronologis Upacara Buka Kaki adalah sebagai berikut: bertanya terlebih dahulu kepada sesepuh waktu yang tepat untuk melaksanakan upacara beserta tatacara lainnya seperti arah dan sebagainya. Kemudian menentukan tempat yang akan dijadikan fondasi rumah yang lazim disebut "kaki" rumah. Malam harinya di rumah lama orang yang akan mendirikan rumah diadakan ritual selamatan yang mengetengahkan makanan. Setelah semua peserta upacara berkumpul yaitu sesepuh, pemilik rumah beserta keluarga besarnya, para tukang atau pekerja, dan masyarakat setempat yang secara spontan mengikuti acara ini. Kemudian 
Ustadz memimpin doa dilanjutkan dengan wirid dan pembacaan tahlil, selesai berdoa kemudian langsung makan-makan, dengan nasi dibungkus daun pisang. Nasi tersebut dinamakan "berkat", ada orang yang makan berkat di lokasi ada pula orang yang makan berkatnya di rumah dengan membawa nasi bungkus daun pisang ke rumah. Selanjutnya peserta yang akan mengikuti melekan berdiam di tempat sementara yang tidak akan mengikuti pulang ke rumah masing-masing. Selesai selamatan si empunya hajat dan masyarakat yang akan mengikuti acara ritual melekan berangkat ke lokasi yang akan di bangun rumah. Di lokasi tersebut sudah ditentukan tempat untuk dijadikan kaki atau fondasi rumah, dengan dipasang tenda untuk tempat berkumpul orang-orang yang akan mengikuti ritual melekan. Selesai melekan, langsung melakukan Buka Kaki yaitu dengan pertama kali mencangkul dilakukan oleh calon pemilik rumah, selanjutnya diteruskan oleh para tukang sampai selesai.

\section{b. Sedang Mendirikan Bangunan}

\section{(1) Upacara Ngunjuk Suhunan}

Ketika mendirikan bangunan rumah setelah dipasang fondasi dilanjutkan dengan pemasangan tiangtiang yang diperkuat dengan palangpalang kayu agar tiang dapat berdiri kokoh. Setelah tiang rumah terpasang kokoh dengan dindingnya, dilanjutkan dengan pemasangan suhunan. Pada saat akan dipasang suhunan terlebih dahulu diadakan selamatan atau upacara yang disebut Ngunjuk Suhunan. Upacara Ngunjuk Suhunan adalah upacara untuk menaikan suhunan, upacara ini disebut juga upacara Naek Suhunan (naek: naik) atau Ngadeg Suhunan (ngadeg: berdiri). Upacara ini diselenggarakan ketika sedang membangun bagian atap atau bagian atas rumah.

Upacara Ngunjuk Suhunan dilaksanakan pada siang hari yaitu sekitar pukul 09.00/10.00 WIB dan selesai waktu salat Dluhur sekitar pukul $12.00 \mathrm{WIB}$. Orang-orang yang terlibat dalam upacara ini adalah si empuya rumah, orang tua si empunya rumah, para sesepuh, ustadz, dan masyarakat sekitar. Adapun yang memimpin upacara adalah ustadz yang biasa mengajarkan pendidikan agama di mesjid setempat. Tempat penyelenggaraan upacara di rumah yang sedang dibangun.

Bagi masyarakat Cirebon, eksistensi suhunan pada rumah merupakan inti bangunan, jadi inti dari rumah pada masyarakat Cirebon terletak pada suhunan (atap). Suhunan atau atap adalah pelidung utama dari rumah; artinya rumah akan terjaga dan terlindungi dari air hujan, panasnya matahari, kotoran dari pohon dan mahluk lainnya. Makna dari suhunan adalah berasal dari kata "suhunan" yang identik dengan "susuhunan" artinya pejabat atau Raja/Sultan yang senantiasa melindungi abdi dan rakyatnya. Tujuan upacara Ngunjuk Suhunan adalah: untuk memelihara dan menjaga tradisi leluhur, untuk mendapatkan berkah dan keselamatan baik si empunya rumah maupun para pekerja (tukang). Dan terbebas dari segala marabahaya, bencana serta agar selalu hidup sehat walafiat. Warga akan merasa tenang jika dapat mengikuti prosesi upacara adat yang telah diwariskan dari leluhurnya (nenek moyang). Dan dapat terhindar dari rasa 
takut dan kekhawatiran jika tidak melaksanakan upacara sementara mereka mampu melaksanakannya.

Dalam upacara Naek Suhunan, perlengkapannya yang harus disediakan adalah sebagai berikut: tumpeng, ikan, sayuran, buah-buahan, bunga tujuh macam (kembang tujuh rupa), seperangkat kemenyan, bendera, kain, padi, kelapa, dan pisang. Tumpeng dan seperangkat makanan seperti sayuran, ikan, dan buah-buahan disediakan untuk para undangan. Biasanya tamu yang diundang adalah para tetangga yang jumlahnya pun tidak banyak kurang lebih sepuluh orang. Sedangkan perlengkapan seperti bunga, kain, bendera, pisang, padi, dan kelapa digunakan untuk dipadang pada suhunan.

Kayu yang digunakan untuk suhunan adalah kayu salam yang terkenal cukup baik karena awet dan keras. Selain itu memang dulu secara tradisional masyarakat diharuskan menggunakan kayu Salam untuk suhunan rumah, namun sekarang kondisinya sudah lain, di Cirebon keberadaan kayu Salam sudah berkurang dan sangat jarang kalaupun ada harganyapun sudah relatif mahal, oleh karena itu dicarikan alternatif lain dengan menggunakan kayu lain tapi tetap harus memperhatikan kualitas baik kekuatan maupun keindahan. Di masyarakat tempo dulu jika membangun rumah tidak menggunakan kayu Salam akan mendapatkan kualat dijauhkan dari keselamatan. Hal ini berkaitan dengan makna kayu Salam sebagai simbol keselamatan bagi orang yang menggunakannya untuk suhunan rumah. Jika tidak ada kayu Salam maka dicarikan kayu lain yang mulus, lurus dan kuat untuk menggantikannya.
Biasanya kayu yang diperuntukkan suhunan panjangnya sekitar 4 meter dan bentuknya bulat atau persegiempat (balok). Jadi pemilihan kualitas kayu untuk suhunan harus diperhatikan sekali selain kuat juga harus mulus dan bagus.

Kayu Salam yang disediakan untuk suhunan sebelum dipasang terlebih dahulu dilakukan ritual dengan membaca doa, shalawat, dan tahlil kemudian dimandikan atau dikeramasi oleh air dari tujuh tempat yaitu dari sumur Jagabayan, air dari Sumur Tujuh atau Sumur Bandung yang terletak di Mesjid Kasepuhan, air dari Sumur Panjunan, air dari sumur Keraton, dan air dari Sumur Sunan Kalijaga. Air dimasukkan kedalam ember kemudian dimasukkan pula bunga tujuh rupa (macam). Makna angka tujuh berasal dari kata "pitu" yang artinya tujuh, "pitu" menjadi "pitulungan" (pertolongan), yang maksudnya adalah agar yang empunya rumah selamanya mendapatkan pertolongan dari Allah swt., Tuhan Yang Mahaesa.

Setelah kayu suhunan dikremasi atau dimandikan dengan air dari tujuh sumur kemudian ditiriskan sampai tidak ada lagi air yang menetes. Setelah kering dibalut dengan kain tujuh lapis yaitu kain sinjang yang biasa digunakan oleh perempuan. Di beberapa tempat seperti di Sidomukti kain yang digunakan untuk membalut Kayu Suhunan adalah Batik Liris, hal ini maknanya berkaitan dengan keindahan, karena batik penuh dengan hiasan dan motif yang indah. Bentuk Batik Liris yang merupakan motif garis yang berjejer lurus dan rata adalah melambangkan harapan kehidupan manusia yang harus tetap, mantap, dan istiqomah dalam rumah tangga. Dengan 
kata lain untuk mewujudkan keadaan rumah tangga yang adem, rukun, dan harmonis, serta tidak mudah tergiur oleh godaan-godaan hidup yang akan memecah belah atau menghancurkan bahtera rumah tangga. Selesai rumah dibangun, atap sudah tertutup rapi biasanya barang-barang berharga seperti kain dan lain-lain akan diambil kembali oleh yang empunya sedangkan makanan yang digantungkan di suhunan diambil atau dimakan oleh para tukang (pekerja).

Orang yang memandikan suhunan harus orang tua si empunya rumah. Cara memandikan suhunan layaknya memandikan jenasah harus hati-hati, tertib, khidmat, dan air dikucurkan harus satu arah tidak boleh bolak-balik. Kalau air mulai dikucurkan dari sebelah kanan sampai keujung sebelah kiri maka dari kiri pun harus satu arah sampai keujung sebelah kanan, demikian seterusnya. Makna cara memandikan kayu suhunan seperti itu adalah agar si empunya rumah tetap tidak kemana-mana dan betah menempati rumah, tidak bosan atau ingin ganti-ganti rumah. Kayu suhunan yang sudah dikeramas atau dimandikan tidak boleh dilangkahi, hal ini merupakan pantangan atau tabu (pamali) bagi masyarakat Cirebon.

Selanjutnya kayu suhunan ditarik ke atas dengan posisi terlentang, tidak boleh berdiri. Sesampainya di atas kemudian dibalut dengan bendera merah putih dan harus dipaku dengan dua buah paku emas. Paku emas sebanyak dua buah melambangkan dua kalimah sahadat sebagai awal masuk agama Islam. Berdampingan dengan bendera merah putih yang dililitkan pada kayu suhunan adalah melambangkan sebagai pengakuan terhadap Negara dan Bangsa Indonesia yaitu pengakuan terhadap Negara Kesatuan Repubik Indonesia (NKRI). Jadi dengan demikian bendera merah putih yang dipaku dengan dua buah paku emas bermakna bahwa Repubik Indonesia tidak dapat dilepaskan dengan Islam atau Republik Indonesia yang diwarnai dengan budaya Islam. Ada juga yang memberikan makna bahwa merah putih itu adalah darah merah dan darah putih diikat menjadi satu agar tidak mudah goyah. Darah merah bermakna jiwa keberanian dan darah putih adalah jiwa kesucian, maksudnya agar keberanian muncul dalam rangka membela kebenaran atau kesucian.

Kemudian ke dalam bendera merah putih dimasukkan rempahrempah namanya "kuat-kuat" yang terdiri dari rangkaian benang seperti rumah laba-laba (rumah gonggong) dengan ramuan-ramuan kemudian diikat menjadi satu dengan bendera merah putih yang dipaku. Ramuan tersebut dijual dipasaran dengan nama bumbu suhunan. Jenis rempahrempahnya adalah serutan kayu salam, serutan kayu manis, dan sejenis serutan kayu-kayuan yang wangi dan manis. Rempah-rempah yang dibalut dengan bendera merah putih adalah dari serutan jenis kayu manis, hal ini sebagai lambang bahwa yang empunya rumah kelak diharapkan mendapatkan kehidupan yang manis-manis atau kebahagiaan dan dijauhkan dari marabahaya.

Suhunan yang sudah dipasang pada kuda-kuda kayu kemudian di bagian penampangnya digantungkan berbagai macam seperti tebu, daun 
beringin, juadah pasar, ikan asin ketek, dan sebagainya. Setelah suhunan terpasang kemudian peserta yang hadir makan bersama-sama dengan hidangan yang telah disediakan oleh si empunya rumah atau makanan yang dibawa dari rumah masing-masing. Makanan yang disediakan oleh si empunya rumah disebut "bogana" yakni makanan yang terdiri dari nasi tumpeng dengan tahu, tempe, dan kelapa. Biasanya nasi tumpeng yang disediakan jumlahnya bervariasi tergantung tingkat perekonomian setiap orang, bisa satu kalau yang sederhana bisa juga lebih banyak lagi jika orang tergolong mampu (kaya).

Selesai prosesi upacara Ngunjuk Suhunan (Ngadeg Suhunan), pekerja selanjutnya meneruskan pekerjaannya sampai selesai. Pemasangan reng agar kuat dan tahan lama biasanya reng tersebut terlebih dahulu direndam beberapa lama, kemudian dikeringkan dan dipasang.

\section{(2) Ritual Pasang Pintu}

Setelah rumah berdiri dengan terpasangnya atap dan dinding rumah, kemudian saatnya melakukan pemasangan pintu. Pada saat pintu akan dipasang terlebih dahulu dilaksanakan sebuah ritual yang lazim dinamakan ritual Pasang Pintu.

Pada ritual Pasang Pintu perlengkapan upacaranya adalah ketupat tiga macam yaitu ketupat segitiga yang dibungkus dengan daun Bambu, Ketupat panjang yang isinya kacang dibungkus dengan daun Kelapa namanya lepet (leupeut:Sunda), dan ketupat segiempat atau ketupat biasa yang terbuat dari beras biasa. Ketiga macam ketupat tadi digantungkan di atas kusen pintu.
Tujuan dari ritual Pasang Pintu adalah agar diberi keselamatan, karena menurut orang tua atau leluhur bahwa di pintu itu ada penunggunya, oleh karena itu harus diberikan syarat-syarat tertentu atau selamatan yang disebut selamatan "Pasang Pintu".

\section{c. Setelah Mendirikan Bangunan}

\section{(1) Upacara Tanam Telur Bungker}

Telur Bungker adalah jenis telur angsa; jenis unggas (Sunda: Soang), yang tidak jadi anak (kacingcalang: Sunda). Upacara Tanam Telur Bungker dilaksanakan setelah pembangunan rumah selesai dan sebelum rumah dihuni.

Tujuan upacara Tanam Telur Bungker adalah sebagai tolak bala, untuk menghindari malapetaka atau bencana yang akan menimpa si empunya rumah beserta keluarganya. Telur Bungker yang ditanam sebagai persyaratan ritual merupakan simbol sifat dari telur bungker tersebut yang merupakan telur yang tidak jadi anak, diharapkan dengan ditanamnya telur bungker di sana, keberadaan mahlukmakhluk halus yang biasa mengganggu manusia tidak akan berkembang; dalam artian berkembang biak menjadi banyak. Dengan tetap sedikit dan menjaganya maka akan terhindarkan dari petaka yang diakibatkan oleh mahluk-makhluk tersebut.

Telur ini ditanam di depan rumah. Sebelum ditanam terlebih dahulu dibungkus dengan kain putih, kemudian dengan dipimpin oleh seorang Ustaz; Ustaz berdoa selesai berdoa terus menanam telur tersebut.

\section{(2) Upacara Kulo Nuwun}

Upacara Kulo Nuwun adalah
upacara yang berkaitan dengan


selesainya pembangunan rumah yang akan ditempati. Si empunya rumah seakan mau memasuki rumah orang lain harus kulo nuwun; artinya meminta izin untuk menempati. Di rumah sudah ada yang menunggu yaitu orang tua atau saudaranya yang telah berusia tua seperti bapaknya, ibunya, uwanya, pamannya, dan kakaknya.

Si empunya rumah datang ke rumah yang baru dari rumah sebelumnya harus membawa "giyung" (pedaringan) dan membawa air yang berasal dari sumur rumah lama. Pedaringan berisi beras putih atau beras yang akan dimakan, pendil air yang ditutup kain, juadah pasar (barang jajanan pasar), dan pisang. Pedaringan yang berisi beras ditempatkan ke tempat yang nantinya akan dijadikan tempat menyimpan beras. Air dibawa menggunakan tempat air seperti kendi. Ke dalam kendi dimasukkan telur ayam bedara; maksudnya ayam yang baru pertama kali bertelur. Air yang dibawa dari sumur lama dicampurkan kedalam air di sumur baru yang terdapat di rumah baru. Selain itu membawa cempor, lampu tempel atau lampu templok yang menggunakan bahan bakar minyak tanah. Lampu dari rumah lama sudah dinyalakan dan sepanjang jalan menuju rumah baru, apinya tidak boleh mati (padam). Cempor ini nantinya diletakkan di samping pedaringan. Si empunya rumah datang dengan rombongan seperti para tetangga dan kerabatnya. Mereka bergerak dengan membaca kalimatkalimat shalawat; selawatan kepada Nabi Muhammad Saw. secara serentak.

Sepanjang jalan pedaringan harus digendong oleh si empunya rumah atau orang yang akan memasuki rumah baru. Sesampainya di depan rumah baru, si calon pemilik rumah harus kulo nuwun terlebih dahulu, dengan mengucapkan kalimat salam (assalamua'laikum warohmatullahi wabarakatuh). Orang yang didalam rumah menyahut, "Wa'alaikumsalam warahmatullahi wabarakatuh. Oh ada tamu, silakan masuk! Kemudian orang yang ada di rumah disuruh mengumandangkan adzan. Setelah itu secara simbolis orang tua atau orang yang ada di rumah menyerahkan rumah kepada anaknya atau pemilik rumah yang sebenarnya. "Ini rumah buat Sira! (Ini rumah buat kamu). Begitu masuk pintu orang tua atau orang yang ada di dalam rumah menasihati orang yang akan menempati rumah tersebut agar betah didalam rumah.

Setelah pemilik rumah masuk kedalam rumah disertai rombongan dari rumah lama, kemudian dilanjutkan dengan makan bersama. Makanan sudah tersedia di dalam rumah.

Tujuan dilaksanakannya upacara Kulo Nuwun adalah agar betah menempati rumah baru dan rumah tersebut benar-benar dapat menaungi, melindungi pemilik beserta keluarganya, juga di rumah yang baru ini dapat membawa rejeki untuk kesinambungan atau kehidupan si penghuni rumah.

Sebelumnya ada perhitungan dengan menggunakan cara-cara sebagai berikut: keluar dari rumah jam berapa, menghadap kemana, masuk ke rumah yang baru dari pintu yang mana. Kemudian dipadukan dengan penghitungan "naktu: Sunda" di Cirebon disebut perhitungan Naga Dina. Penghitungan ini berdasarkan pada hari dan tanggal lahir yang 
bersangkutan, si empunya rumah. Naga Dina maksudnya jangan sampai masuk kedalam naga atau berhadapan dengan naga, jika masuk atau berhadapan akan mendapatkan kecelakaan, akan kena malapetaka. Jangan sampai masuk kedalam rumah melalui pintu yang ada naganya, jika naga ada di pintu tersebut maka cari pintu lain yang bebas dari naga, agar selamat. Hasil dari perhitungan "Naktu/ Naga Dina" akan diketahui bahwa masuk ke rumah baru harus melalui pintu yang mana dan arah yang manapula. Orang yang dapat menghitung tersebut adalah orang tua atau para sesepuh yang mengetahui dan menguasai Primbon; kumpulan tulisan yang berisi pengetahuan tradisional tentang adat istiadat warisan peninggalan leluhur (nenek moyang).

\section{(3) Upacara Borong Rumah \\ (Beli/Ngebeliin)}

Upacara ini dilakukan ketika rumah sudah selesai dibangun. Menurut kepercayaan leluhur bahwa rumah yang telah selesai dibangun bukan milik yang empunya rumah tapi milik tukang atau pekerja bangunan. Untuk serah terima biasanya diadakan prosesi "beli atau ngebeliin" dari tukang kepada yang empunya rumah. Jadi si empunya rumah harus membeli dari tukang atau pekerja, ini berlaku di Kampung Adat Keputihan yang diwariskan secara turun temurun dari leluhur sampai ke generasi sekarang. Rumah yang sudah jadi atau diselesaikan oleh tukang, kepemilikannya harus melalui proses dibeli dari tukang ke si empunya rumah.

Terjadi adu tawar antara tukang dengan yang empunya rumah. Kalau kata tukang harganya $\mathrm{Rp} 1.000 .000,-$, $500.000,-, 250.000,-$ maka yang beli yaitu si empunya rumah harus berani membelinya serta dibayar kontan. Dan harga tersebut sebenarnya disesuaikan dengan standar harga kebiasaan terjadi jual beli antara tukang dan si empunya rumah di Kampung Adat Keputihan. Dan juga disesuaikan dengan keadaan rumah yang dibangun. Jadi tidak mungkin ada harga yang tidak dapat terjangkau oleh si empunya rumah, dan hal tersebut sebenarnya hanya ritual untuk melaksanakan adat istiadat leluhur saja.

Setelah terjadi upacara Borong Rumah maka rumah yang tadinya milik tukang sekarang resmi menjadi milik si empunya rumah baik secara adat maupun secara kenegaraan. Istilahnya yang memiliki rumah itu adalah yang menunggu atau nungguin rumah. Sehingga dengan terjadinya jual beli antara tukang dengan si empunya rumah maka telah terjadi perpindahan tanggung jawab yang menunggu rumah. Dan prosesi upacara Borong Rumah ini tujuannya adalah agar yang menunggu rumah mendapatkan keselamatan.

\section{PENUTUP}

Masyarakat adat atau komunitas adat merupakan kumpulan orang yang masih taat dan patuh memegang tradisi leluhur. Dalam kehidupan sehari-hari mereka tetap menjaga dan memelihara tatacara hidup leluhur yang diwariskan dari generasi ke generasi. Peninggalan leluhur ini termasuk didalamnya adalah arsitektur rumah yang mereka huni. Secara akumulasi tata letak, struktur, dan fungsi rumah yang mereka tempati selalu mengikuti teknologi yang telah diturunkan dari leluhurnya.

Salah satu masyarakat yang masih bersikukuh menjalankan adat 
istiadat leluhurnya adalah masyarakat adat Kampung Keputihan yang terletak di wilayah Sumber, Kecamatan Weru, Kabupaten Cirebon, Provinsi Jawa Barat. Berbeda dengan kampung adat lainnya, Kampung Keputihan ini tampaknya merupakan kampung adat yang dapat dikatakan "hidup enggan mati tak mau". Beberapa bangunan sudah berkurang bahkan sudah punah seperti rumah adat yang dulunya berjumlah 17 buah sekarang tinggal 13 rumah lagi, sementara itu lumbung padi (Sunda: Leuit) sekarang sudah tidak ada lagi padahal dulunya ada begitu pula bangunan-bangunan tempat bermusyawarah.

Warga Kampung Keputihan yang berpindah keluar kampung adat merupakan ungkapan kebosanan mereka dalam menjalankan adat istiadat leluhurnya, mereka pindah keluar ingin memiliki rumah yang permanen dan sebagainya. Sementara itu, warga yang tinggal 13 rumah itu, sebagian sudah mulai ada pergeseranpergeseran dari ketentuan-ketentuan adat seperti lantai yang sudah ditembok (dipelur), atap menggunakan asbes atau seng, padahal aturan leluhur lantai harus tanah, atap harus dari daun tebu/kelapa. Namun demikian ketentuan-ketentuan adat lainnya masih mereka pegang, dan mereka masih tetap merupakan komunitas yang menjalankan dan memelihara adat istiadat leluhurnya termasuk didalamnya arsitektur rumah.

Arsitektur rumah di Kampung Keputihan secara umum masih mereka jalankan sesuai ketentuan adat di antaranya: rumah harus menghadap ke Selatan atau Utara, genting rumah harus dari dedaunan seperti daun tebu/kelapa, bentuk atap atau suhunan adalah suhunan pelana yakni tipologi atap yang memanjang membentuk rumah persegi panjang. Sumur dan kamar mandi harus berada di samping kanan rumah, jendela tidak boleh menggunakan kaca dan lantai harus dari tanah.

Struktur rumah harus natural; berasal dari pepohonan mulai dari tiang, atap, genting, dinding, kursi, jendela, dan pintu. Balok suhunan dari kayu salam, genting dari daun tebu atau kelapa, dinding dan langit-langit dari bilik yang terbuat dari anyaman bambu, jendela dari kayu, pintu dari kayu dan bambu, dan kursi dari bambu. Sementara itu lantai rumah harus tetap dari tanah, jemuran diletakkan di halaman depan rumah, kandang hewan diletakan dihalaman depan sebelah kanan.

Mendirikan rumah sebagian dengan bergotong royong sisanya dikerjakan oleh tukang atau pekerja bangunan. Sebelum mendirikan rumah mereka melakukan persiapan terlebih dahulu seperti bermusyawarah dengan keluarga, saudara, dan tetangga. Kemudian menetapkan lahan yang akan dijadikan bangunan dan pengadaan bahan.

Masyarakat Kampung Keputihan yang masih memegang adat istiadat leluhurnya dalam mendirikan rumah diwarnai dengan berbagai upacara adat seperti upacara Buka Kaki yaitu upacara yang dilaksanakan sebelum mendirikan bangunan. Upacara ini merupakan langkah awal untuk memasang fondasi rumah dan sumur. Upacara Ngunjuk Suhunan dilaksanakan ketika pembangunan sedang berjalan. Upacara Ngunjuk 
Suhunan merupakan acara ritual pada waktu akan memasang suhunan (wuwung). Upacara Tanam Telur Bungker, Borong Rumah, Kulo Nuwun, ketiga upacara ini dilaksanakan pada saat pembangunan rumah telah selesai. Upacara Tanam Telur Bungker adalah untuk menjaga agar perkembangbiakan makhluk halus yang suka mengganggu dapat diminimalisir, sehingga penghuni rumah dapat terhindar dari gangguannya. Upacara Borong Rumah adalah pengambil-alihan rumah dari tukang (pekerja bangunan) kepada pemilik yang sebenarnya; hal ini disebabkan ada anggapan bahwa siapa yang menunggu rumah dialah pemiliknya. Selama membangun, tukang (pekerja bangunan) yang menunggu rumah sehingga dianggap leluhur dialah pemiliknya oleh karena itu untuk ganti pemilik ke pemilik sebenarnya harus diadakan upacara Borong Rumah. Dalam upacara ini si pemilik harus membeli rumah dari tukang (pekerja bangunan). Kulo Nuwun adalah upacara meminta izin kepada penunggu bahwa si pemilik akan menghuni rumah tersebut. Dari upacara-upacara yang berkaitan dengan pembangunan rumah di Kampung Keputihan tujuannya adalah agar si empunya rumah diberikan keselamatan, kehidupan yang baik, betah di rumah yang baru dan terhindar dari gangguan makhlus halus.

\section{DAFTAR PUSTAKA}

Sujana, TD et.al. 2006

Legenda Cirebon; Cerita tentang Asal-Usul Tokoh \& Peristiwa. Cirebon: Kebudayaan dan Pariwisata Kota Cirebon.

Solichin, H.I.
Pelestarian Bangunan Kuno Sebagai Benda Cagar Budaya (Makalah) : Cirebon.

Moh, Alimansyur et.al. 1990/1991
Arsitektur Tradisional Daerah Sumatera Selatan. Jakarta : Proyek Inventarisasi dan Dokumentasi Kebudayaan Daerah, Direktorat Sejarah dan Nilai Tradisional, Departemen Pendidikan dan Kebudayaan.

Hermana, et.al. 2006

Sistem Teknologi Tradisional. Bandung : Departemen Kebudayaan dan Pariwisata, Balai Kajian Sejarah dan Nilai Tradisional.

Khadijah, et.al. 2006

Potensi Wisata Budaya Kota Cirebon. CV. Neo Technologi Cirebon : Dinas Kebudayaan dan Pariwisata Kota Cirebon. 